\title{
In vitro antioxidant and a-amylase inhibitory properties of watermelon seed protein hydrolysates
}

\author{
Rotimi Olusanya Arise ${ }^{1 *}$, Abeeb Abiodun Yekeen ${ }^{1}$, Oluwafemi Emmanuel Ekun ${ }^{1,2}$ \\ ${ }^{1}$ Department of Biochemistry, Faculty of Life Sciences, University of Ilorin, Ilorin, Nigeria \\ ${ }^{2}$ Department of Biochemistry, Faculty of Sciences, Adekunle Ajasin University, Akungba-Akoko, Nigeria \\ ${ }^{\star}$ Corresponding author, E-mail: ariserotimi@gmail.com
}

\begin{abstract}
Proteins from watermelon (Citrullus lanatus L.) seed were isolated using acid-induced precipitation method and then hydrolysed using pepsin, trypsin and alcalase. The hydrolysates were investigated for in vitro antioxidant and a-amylase inhibitory properties. The yield of peptic hydrolysis $(68.9 \pm 1.0 \%)$ was significantly higher than of tryptic $(41.4 \pm 1.1 \%)$ and alcalase $(38.5 \pm 0.5 \%)$ hydrolysis. Peptic hydrolysate showed the highest radical-scavenging ability whereas tryptic hydrolysate gave the highest reducing ability. In a concentrationdependent manner, the hydrolysates demonstrated potent $\alpha$-amylase inhibitory ability with alcalase and tryptic hydrolysates exhibiting $86.0 \pm 3.9$ and $83.0 \pm 3.5 \%$ a-amylase inhibition respectively $\left(\mathrm{IC}_{50} 0.149\right.$ to $\left.0.234 \mathrm{mg} \mathrm{mL}^{-1}\right)$. Kinetic analysis revealed that the three enzyme hydrolysates inhibited $\alpha$-amylase activity via a non-competitive inhibition mechanism. The results therefore indicate that these multidirectional bioactivities of watermelon seed protein hydrolysates may serve as useful tools in the formulation of antidiabetic agents.
\end{abstract}

Key words: alcalase, antioxidant, antidiabetic, Citrullus lanatus, pepsin, trypsin.

Abbreviations: CE, catalytic efficiency; CSPH, Citrullus lanatus seed protein hydrolysate; CSPI, Citrullus lanatus seed protein isolate; $\mathrm{DH}$, degree of hydrolysis; DM, diabetes mellitus; TCA, trichloroacetic acid.

\section{Introduction}

Food-based bioactive peptides have been continuously popular due to their therapeutic abilities. Of particular importance are peptides with multifunctional abilities that can be used in the prevention and treatment of diet-related diseases such as diabetes (Zambrowicz et al. 2014). One plant that has been implicated in the management of dietrelated diseases such as hypertension is Citrullus lanatus L. (Arise et al. 2016). C. lanatus (watermelon) belongs to the Cucurbitaceae family, and the species C. lanatus includes the "cultivated watermelon", lanatus; and the "wild or citron melon", citroides (Singh, Matta 2010).

Studies have shown that the protein content of the seed is within the range of 30.63 to $43.60 \%$, which puts it among some of the richest food sources of proteins (Arise et al. 2016). Thus, this makes it a good candidate to explore for the production of bioactive peptides (Singh, Matta 2010; Jacob et al. 2015). Various parts of C. lanatus have been reported traditionally and in several studies to have therapeutic properties, among which are their antihypertensive, antiinflammatory, antidiabetic, antioxidant, antimicrobial, antiplasmodial, hepatoprotective and analgesic effects (Singh, Matta 2010; Erhirhie, Ekene 2013; Mundi, Aluko 2014; Sani 2014; Honga et al. 2015; Arise et al. 2016).

C. lanatus is used as traditional food for diabetes and hypertension treatment. Diabetes mellitus (DM) is an endocrine system disease, characterised by chronic hyperglycaemia with impaired carbohydrate, fat and protein metabolism, which causes metabolic disorders resulting in multiple organ damage syndromes. Control of blood glucose levels remains the most effective therapeutic approach for DM (Matsui et al. 1996; Yu et al. 2012). Glycoside-trimming enzymes are important in the digestion of carbohydrates. Salivary $\alpha$-amylase initiates the hydrolysis of starch, and in the stomach pancreatic a-amylase completes the conversion into disaccharides and short oligosaccharides. Intestinal a-glucosidases then break down disaccharides into monosaccharides (glucose), which are readily absorbed into the blood stream (Oboh et al. 2011).

Inhibition of $a$-amylase and $\alpha$-glucosidase by commercially available drugs (e.g. acarbose and voglibose) is an important therapeutic approach for the control of postprandial hyperglycaemia. However, it has been reported that these inhibitors are associated with side effects such as abdominal pain, flatulence, diarrhoea etc. in diabetic patients. Thus, efforts have been directed at investigating food-based inhibitors of these enzymes that are free of such side effects (Adisakwattana et al. 2012).

Oxidative stress and oxidative damage to tissues are common results of some chronic human diseases, like DM. Persistent hyperglycaemia causes increased production of free radicals as a result of glucose auto-oxidation 
and protein glycosylation (Lipinski 2001; Asmat et al. 2015; Kayama et al. 2015). In order to expand treatment options, there is a need to explore the connection between free radicals, hyperglycaemia and diabetes (Oboh et al. 2011). Hence, this study was aimed at investigating the in vitro antioxidant and $\alpha$-amylase inhibitory properties of the hydrolysates obtained from enzymatic digestion of watermelon seed proteins.

\section{Materials and methods}

\section{Materials}

Citrullus lanatus L. (watermelon) fruit was purchased from a local fruit store in the Tanke area, Ilorin, Kwara state, Nigeria, and the seed was authenticated at the Department of Plant Biology, University of Ilorin, Ilorin, Nigeria where voucher no. UILH/001/1149 was deposited for record purposes. Trizma-base, $n$-hexane, pepsin (from porcine gastric mucosa), trypsin (from bovine pancreas), alcalase (protease from Bacillus licheniformis), bovine serum albumin, $\alpha$-amylase (from porcine pancreas), dinitrosalicylic acid and maltose were products of SigmaAldrich (USA), and glycine, trichloroacetic acid (TCA) and ascorbic acid were products of $\mathrm{BDH}$ Chemical Limited (Poole, England). All other reagents used were of analytical grade.

\section{Isolation of C. lanatus seed protein}

C. lanatus seeds were dried and pulverised before storage in an air-tight container at $4{ }^{\circ} \mathrm{C}$. The powdered seeds were defatted using $\mathrm{n}$-hexane as previously described by Wani et al. (2011). The pulverised seeds were defatted using Soxhlet apparatus for a period of five hours. The defatted meal was then de-solventized at room temperature and ground again to obtain a fine powder, termed defatted seed meal, which was then refrigerated until later use.

The protein component of the defatted meal was extracted using the method described by Alashi et al. (2014) with slight modifications. Defatted watermelon seed meal was suspended in $0.1 \mathrm{M} \mathrm{NaOH}$ pH 12.0 at a meal to solvent ratio of $1: 10$, and stirred for $1 \mathrm{~h}$ to facilitate alkaline solubilisation. This was then centrifuged at $18^{\circ} \mathrm{C}$ and 3000 $\mathrm{rpm}$ for $10 \mathrm{~min}$. Two additional extractions of the residue from the centrifugation process were carried out with the same volume of $0.1 \mathrm{M} \mathrm{NaOH}$ and the supernatants were pooled. The $\mathrm{pH}$ of the supernatant was adjusted to $\mathrm{pH}$ 4.0 to facilitate acid-induced protein precipitation using $1 \mathrm{M} \mathrm{HCl}$ solution; the precipitate formed was recovered by centrifugation as described above. The precipitate was washed with distilled water, adjusted to $\mathrm{pH} 7.0$ using $1 \mathrm{M}$ $\mathrm{NaOH}$, freeze-dried and the protein isolate termed CSPI was refrigerated until required for further analysis. Protein yield was determined as described by Arise et al. (2015) using the formula below:

Protein Yield \% = Mass of protein isolate $(\mathrm{g}) /$ Mass of defatted watermelon seed meal $(\mathrm{g}) \times 100(\%)$.
Preparation of C. lanatus seed protein hydrolysates

The protein isolate was hydrolysed using the methods described by Udenigwe et al. (2009) with slight modifications. The conditions for hydrolysis were tailored for each enzyme in order to optimise its activity. Hydrolysis was done using each of pepsin $\left(\mathrm{pH} 2.2,37^{\circ} \mathrm{C}\right)$, trypsin $(\mathrm{pH}$ $\left.8.0,37^{\circ} \mathrm{C}\right)$ and alcalase $\left(\mathrm{pH} 8.0,60^{\circ} \mathrm{C}\right)$. The protein isolate $(5 \% \mathrm{w} / \mathrm{v})$ was dissolved in the appropriate buffer (phosphate buffer, $\mathrm{pH} 8.0$ for trypsin and alcalase; and glycine buffer, $\mathrm{pH} 2.2$ for pepsin). The enzyme was added to the slurry at an enzyme-substrate ratio (E:S) of 1:100. Digestion were performed at the specified conditions for $5 \mathrm{~h}$ with continuous stirring before the enzyme was inactivated by immersing the reaction vessel in boiling water (95 to 100 ${ }^{\circ} \mathrm{C}$ ) for $15 \mathrm{~min}$. Undigested proteins were precipitated by adjusting the $\mathrm{pH}$ to 4.0 with $2 \mathrm{M} \mathrm{HCl}$ (or $2 \mathrm{M} \mathrm{NaOH}$ as appropriate) followed by centrifugation at $4000 \mathrm{rpm}$ for $30 \mathrm{~min}$. The supernatant containing target peptides was then collected, analysed for degree of hydrolysis and then freeze-dried. The freeze-dried hydrolysate termed CSPH was then refrigerated until further analysis. Protein content of samples was determined using the biuret assay method of Gornall et al. (1949) with bovine serum albumin (BSA) as standard.

\section{Determination of degree of hydrolysis}

Degree of hydrolysis was determined by calculating the percentage of soluble peptide in $10 \%$ trichloroacetic acid (TCA) in relation to total protein content of the protein isolate according to the method described by Hoyle and Merritt (1994) with slight modifications. $500 \mu \mathrm{L}$ of CSPH was added to $500 \mu \mathrm{L}$ of $20 \%$ TCA to produce $10 \%$ TCA soluble material. The mixtures were left to stand for $30 \mathrm{~min}$ to allow precipitation, followed by centrifugation (3500 rpm for $15 \mathrm{~min}$ ). The supernatant was analysed for protein content using the biuret assay method of Gornall et al. (1949) with bovine serum albumin (BSA) as standard. The degree of hydrolysis was computed as shown below:

Degree Hydrolysis \% = Soluble peptide in 10\% TCA $\left(\mathrm{mg} \mathrm{mL}^{-1}\right) /$ Total protein content of isolate $\left(\mathrm{mg} \mathrm{mL}^{-1}\right) \times$ $100(\%)$.

\section{Determination of peptide yield}

The percentage peptide yield was determined using the method described by Girgih et al. (2011). The peptide yield (\%) of CSPH was calculated as the ratio of peptide weight of lyophilised hydrolysate to the protein weight of protein isolate as shown:

Peptide Yield \% = Peptide weight of lyophilised hydrolistae

$\left(\mathrm{mg} \mathrm{mL}^{-1}\right) /$ Protein weight of lyophilised isolate $(\mathrm{mg}$

$$
\left.\mathrm{mL}^{-1}\right) \times 100(\%) \text {. }
$$

\section{Determination of ferric-reducing antioxidant power}

The ability of CSPHs to reduce $\mathrm{Fe}^{3+}$ to $\mathrm{Fe}^{2+}$ was determined according to the method of Oyaizu (1986) as described by Zhang et al. (2008). Stock CSPHs and ascorbic acid were 
prepared in distilled water. Aliquot amounts $(1.0 \mathrm{~mL})$ of varying concentrations $\left(0.20\right.$ to $\left.0.80 \mathrm{mg} \mathrm{mL}^{-1}\right)$ of $\mathrm{CSPH}$ in $0.20 \mathrm{M}$ phosphate buffer ( $\mathrm{pH}$ 6.6) were mixed with $1.00 \mathrm{~mL}$ of $1 \%$ potassium ferricyanide solution. The blank contained no sample but $1.0 \mathrm{~mL}$ of phosphate buffer mixed with $1.0 \mathrm{~mL}$ of the potassium ferricyanide solution. All the reaction mixtures were then incubated at $50{ }^{\circ} \mathrm{C}$ for 20 min followed by the addition of $1.0 \mathrm{~mL} 10 \% \mathrm{w} / \mathrm{v}$ aqueous trichloroacetic acid. $1.0 \mathrm{~mL}$ of the incubation mixture was added to $1.0 \mathrm{~mL}$ distilled water and $0.2 \mathrm{~mL}$ of $0.1 \%$ ferric chloride, followed by incubation at room temperature for $10 \mathrm{~min}$. The solution was then centrifuged at $3000 \mathrm{rpm}$ for $10 \mathrm{~min}$ and the absorbance of the clear supernatant was determined at $700 \mathrm{~nm}$ wavelength. Ascorbic acid was used as the standard antioxidant and aqueous solutions of known $\mathrm{Fe}^{2+}$ concentrations $\left(\mathrm{FeSO}_{4} \times 7 \mathrm{H}_{2} \mathrm{O} ; 2.0,1.0,0.5\right.$, 0.25 and $0.125 \mathrm{mM}$ ) were used for calibration and results expressed in terms of $\mathrm{mM}$ of $\mathrm{Fe}^{2+}$ released. All tests were performed in triplicate.

\section{Determination of superoxide anion radical-scavenging capacity}

The superoxide radical-scavenging activity of CSPHs was determined using the method developed by Gao et al. (1998) as modified by Alashi et al. (2014). The superoxide anion radical-scavenging activity was assayed by measuring the inhibition of the autoxidation of pyrogallol. Aliquot amount $(800 \mu \mathrm{L})$ of the CSPH in distilled water $(0.5$ to $2.0 \mathrm{mg} \mathrm{mL}-1$ ) was mixed with $800 \mu \mathrm{L}$ of $50 \mathrm{mM}$ Tris- $\mathrm{HCl}$ buffer ( $\mathrm{pH}$ 8.3) containing $1 \mathrm{mM}$ EDTA. Four hundred (400) $\mu \mathrm{L}$ of $1.5 \mathrm{mM}$ pyrogallol dissolved in $10 \mathrm{mM} \mathrm{HCl}$ was then added to each tube in the dark. Distilled water was used as blank and in thecontrol to replace the hydrolysate. Absorbance readings were taken immediately at $420 \mathrm{~nm}$ for $4 \mathrm{~min}$ at room temperature and superoxide scavenging activity of hydrolysate was calculated as follows:

$\mathrm{O}_{2}^{-}$-Scavenging Capacity $(\%)=\left[\left(\Delta \mathrm{A} \mathrm{min}^{-1}\right)_{\text {control }}-(\Delta \mathrm{A}\right.$ $\left.\left.\mathrm{min}^{-1}\right)_{\text {sample }}\right] /\left(\Delta \mathrm{A} \mathrm{\textrm {min } ^ { - 1 }}\right)_{\text {control }} \times 100$.

The concentration of CSPH that inhibited pyrogallol autoxidation by $50 \%\left(\mathrm{IC}_{50}\right.$ ) was interpolated from a nonlinear regression plot of $\mathrm{O}_{2}^{-}$-scavenging capacity versus hydrolysate concentrations using GraphPad Prism version 6.0 (GraphPad Software, San Diego, CA, USA). Experiments were performed in triplicate.

\section{Determination of a-amylase inhibition}

An $\alpha$-amylase-inhibitory assay was carried out according to the method of Bernfield (1951) as reported by Oboh et al. (2011). Briefly, $125 \mu \mathrm{L}$ of hydrolysate $(0.5$ to $2.0 \mathrm{mg}$ $\left.\mathrm{mL}^{-1}\right)$ was placed in test tubes and $125 \mu \mathrm{L}$ of $20 \mathrm{mM}$ sodium phosphate buffer $(\mathrm{pH} 6.9$, with $6 \mathrm{mM} \mathrm{NaCl})$ containing $\alpha$-amylase solution $\left(0.5 \mathrm{mg} \mathrm{mL}^{-1}\right)$ was added. The content of each tube was pre-incubated at $25^{\circ} \mathrm{C}$ for $10 \mathrm{~min}$, after which $125 \mu \mathrm{L}$ of $1 \%$ starch solution in $20 \mathrm{mM}$ sodium phosphate buffer ( $\mathrm{pH} 6.9$, with $6 \mathrm{mM} \mathrm{NaCl}$ ) was added at timed intervals. The reaction mixtures were incubated at $25^{\circ} \mathrm{C}$ for $10 \mathrm{~min}$. The reaction was terminated by adding $250 \mu \mathrm{L}$ of dinitrosalicylic acid (DNS) colour reagent and further incubated in boiling water for $5 \mathrm{~min}$ and cooled to room temperature. The content of each test tube was diluted with $2.5 \mathrm{~mL}$ distilled water and the absorbance measured at $540 \mathrm{~nm}$. A control was prepared using the same procedure except that the hydrolysate was replaced with distilled water. The $\alpha$-amylase-inhibitory activity was calculated as shown:

$\%$ Inhibition $=\left(\mathrm{A}_{\text {control }}-\mathrm{A}_{\text {sample }}\right) / \mathrm{A}_{\text {control }} \times 100$.

The concentration of hydrolysate resulting in 50\% inhibition of enzyme activity $\left(\mathrm{IC}_{50}\right)$ was determined from a plot of percentage inhibition against hydrolysate concentrations using GraphPad Prism version 6.0 (GraphPad Software, San Diego, CA, USA).

\section{Determination of kinetic parameters of a-amylase inhibition}

The kinetic study of $\alpha$-amylase inhibition by CSPHs was conducted according to the modified method described by Ali et al. (2006). $125 \mu \mathrm{L}$ of the hydrolysate was preincubated with $125 \mu \mathrm{L}$ of $\alpha$-amylase solution for $10 \mathrm{~min}$ at $25{ }^{\circ} \mathrm{C}$ in a set of tubes. In another set of tubes, $250 \mu \mathrm{L}$ of phosphate buffer ( $\mathrm{pH}$ 6.9) was also pre-incubated with $125 \mu \mathrm{L}$ of $\alpha$-amylase solution. Starch solution $(125 \mu \mathrm{L})$ of increasing concentrations ( 1.0 to $8.0 \mathrm{mg} \mathrm{mL}^{-1}$ ) was added to both sets of reaction mixtures to initiate the reaction. The mixture was then incubated for $10 \mathrm{~min}$ at $25^{\circ} \mathrm{C}$, and then boiled for $5 \mathrm{~min}$ after the addition of $250 \mu \mathrm{L}$ of DNS reagent to stop the reaction. The amount of reducing sugars released was determined spectrophotometrically from a maltose standard curve and converted to reaction velocities as shown below:

Specific Activity $\left(\mu \mathrm{mol} \mathrm{mg}\right.$ protein $\left.{ }^{-1} \mathrm{~min}^{-1}\right)=$ Maltose released / Incubation time $\times \mathrm{M}_{\mathrm{E}}$,

where maltose concentration is in $\mu \mathrm{mol} \mathrm{mL} L^{-1}$; Incubation time $=10 \mathrm{~min} ; \mathrm{M}_{\mathrm{E}}=$ amount of enzyme (in $\mathrm{mg}$ ) in reaction mixture

A double reciprocal plot (1/V versus $1 /[\mathrm{S}])$, where $\mathrm{V}$ is reaction velocity and $[\mathrm{S}]$ is substrate concentration was plotted. The mode of inhibition and the kinetic parameters $\left(K_{m}, K^{\prime}{ }_{m}, V_{\max }, V^{\prime} \max , C E\right.$ and $\left.C E^{\prime}\right)$ of $\alpha$-amylase inhibition by CSPHs were determined by analysis of the double reciprocal plot. The inhibition constant $\left(K_{i}\right)$ was determined as the intercept on the $\mathrm{x}$-axis from the secondary plot of the slopes of the Lineweaver-Burk plots against inhibitor concentrations using Microsoft Excel version 2016.

\section{Statistical analysis}

Data were expressed as themean of three replicates \pm standard deviation (SD). The data were subjected to analysis of variance and Tukey's multiple range tests using GraphPad Prism version 6.0 (GraphPad Software, San Diego, CA, USA). Differences were considered significant at $p<0.05$. 
Table 1. Yields of protein isolate, hydrolysates and degree of hydrolysis. Values represent the means of triplicate determinations \pm standard deviation (SD). Values with different letters are significantly different at $p<0.05$

$\begin{array}{lccc}\text { Parameter/Enzyme } & & \text { Degree of hydrolysis (\%) } & \text { Peptide yield (\%) } \\ \text { Protein yield of isolate (\%) } & 18.91 & - & - \\ \text { Pepsin } & - & 19.38 \pm 0.86^{\mathrm{a}} & 68.90 \pm 1.00^{\mathrm{a}} \\ \text { Trypsin } & - & 26.26 \pm 0.27^{\mathrm{b}} & 41.38 \pm 1.10^{\mathrm{b}} \\ \text { Alcalase } & - & 13.16 \pm 1.82^{\mathrm{c}} & 38.50 \pm 0.51^{\mathrm{c}}\end{array}$

\section{Results}

Yields of protein isolate, hydrolysis and degree of hydrolysis The percentage protein yield of isolate, degree of hydrolysis and peptide yield of hydrolysis are depicted in Table 1. Following isolation, the percentage protein yield obtained was $18.91 \%$. There were significant differences $(p<0.05)$ between the degree of hydrolysis of CSPI by each of pepsin, trypsin and alcalase. The degree of tryptic hydrolysis was higher $(p<0.05)$ than the degrees of peptic and alcalase hydrolysis. However, peptic hydrolysis gave a significantly higher degree of hydrolysis than alcalase hydrolysis. Also, the percentage peptide yield of peptic hydrolysis was significantly higher than these of tryptic and alcalase hydrolysis, while trypsin yielded a higher percentage $(\mathrm{p}<$ $0.05)$ than alcalase.

\section{a-Amylase inhibition}

Fig. 1 shows the a-amylase-inhibitory effect of peptic, tryptic and alcalase hydrolysates obtained from watermelon seed protein. In a concentration-dependent manner, all CSPHs demonstrated percentage a-amylase inhibition beyond $50 \%$ at concentrations of 0.5 to $2.0 \mathrm{mg} \mathrm{mL}^{-1}$.

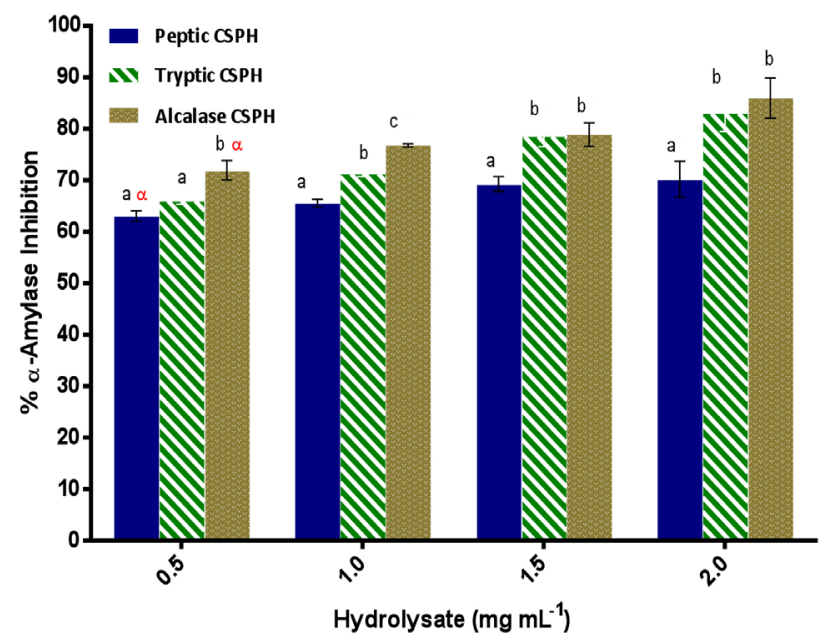

Fig. 1. a-Amylase-inhibitory property of Citrullus lanatus seed protein hydrolysates. Each bar represents the mean of triplicate determinations \pm SD. Bars at the same concentration but with different Latin letters $(\mathrm{abc})$ are significantly different $(p<0.05)$. Bars of the same hydrolysate at different concentrations having the same Greek letters $(\alpha \beta)$ are not significantly different $(p>$ $0.05)$.
Alcalase CSPH exhibited percentage $\alpha$-amylase inhibition values that were highest at all study concentrations and were significantly higher $(p<0.05)$ than those of peptic CSPH. Percentage $\alpha$-amylase inhibition values of alcalase CSPH were only significantly higher than those of tryptic $\mathrm{CSPH}$ at lower concentrations of 0.5 and $1.0 \mathrm{mg} \mathrm{mL}^{-1}$. Percentage $\alpha$-amylase inhibition values of tryptic CSPH were higher $(p<0.05)$ than those of peptic CSPH at all study concentrations except at $0.5 \mathrm{mg} \mathrm{mL}^{-1}$, where there was no significant difference.

Fig. 2 shows the $50 \%$ a-amylase-inhibitory concentrations $\left(\mathrm{IC}_{50}\right)$ of CSPHs. The $\mathrm{IC}_{50}$ of peptic $(0.165$ $\left.\mathrm{mg} \mathrm{mL} \mathrm{m}^{-1}\right)$ and alcalase $\left(0.149 \mathrm{mg} \mathrm{mL}^{-1}\right)$ CSPHs were not significantly different but both were significantly lower $(p<$ $0.05)$ than that of tryptic CSPH $\left(0.234 \mathrm{mg} \mathrm{mL}^{-1}\right)$.

\section{Kinetics of a-amylase inhibition}

The effects of peptic, tryptic and alcalase CSPHs on the kinetic parameters of $\alpha$-amylase-catalysed degradation of starch to simple reducing sugars are illustrated in Fig. 3 to 5, respectively. The figures show the Lineweaver-Burk plots of $\alpha$-amylase-catalysed degradation of starch in the absence and presence of three concentrations of each of peptic,

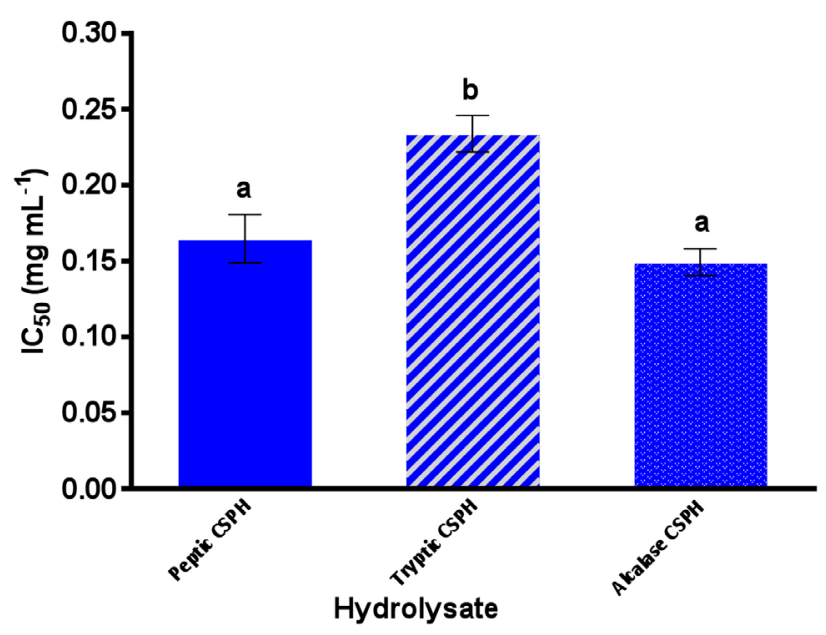

Fig. 2. Values of $50 \%$ a-amylase-inhibitory concentration $\left(\mathrm{IC}_{50}\right)$ of Citrullus lanatus seed protein hydrolysates. Each bar represents the mean of triplicate determinations \pm SD. Bars at the same concentration but with different Latin letters $(\mathrm{abc})$ are significantly different $(p<0.05)$. 
Table 2. Kinetic parameters of $\alpha$-amylase-catalysed degradation of starch in the absence and presence of Citrullus lanatus seed protein hydrolysates. $K_{m}$ or $K_{m}^{\prime}$, Michaelis constant in the presence and absence of CSPH; $V_{\max }$ or $V_{\text {max }}^{\prime}$, Maximum reaction rate in the presence and absence of $\mathrm{CSPH}$; CE, catalytic efficiency; $K_{i}$, enzyme-inhibitor dissociation constant

\begin{tabular}{lcccccccccc} 
Catalytic parameter & No & \multicolumn{4}{c}{ Peptic CSPH $\left(\mathbf{m g ~ m L}^{-1}\right)$} & \multicolumn{4}{c}{ Tryptic CSPH $\left(\mathbf{m g ~ m L}^{-1}\right)$} & \multicolumn{4}{c}{ Alcalase CSPH $\left(\mathbf{m g ~ m L}^{-1}\right)$} \\
& inhibitor & $\mathbf{0 . 5}$ & $\mathbf{1 . 0}$ & $\mathbf{1 . 5}$ & $\mathbf{0 . 5}$ & $\mathbf{1 . 0}$ & $\mathbf{1 . 5}$ & $\mathbf{0 . 5}$ & $\mathbf{1 . 0}$ & $\mathbf{1 . 5}$ \\
& 6.639 & 6.290 & 4.440 & 8.088 & 4.283 & 6.915 & 4.610 & 3.705 & 4.936 & 4.868 \\
$K_{m}$ or $K_{m}^{\prime}\left(\mathrm{mg} \mathrm{mL}^{-1}\right)$ & 4.409 & 2.774 & 1.402 & 1.268 & 1.497 & 1.641 & 0.791 & 0.880 & 0.760 & 0.547 \\
$V_{\max }$ or $V_{\max }^{\prime}\left(\mu \mathrm{mol} \mathrm{mg}^{-1} \mathrm{~min}^{-1}\right)$ & 0.664 & 0.441 & 0.316 & 0.157 & 0.349 & 0.237 & 0.171 & 0.238 & 0.154 & 0.112 \\
$\mathrm{CE}\left(\mu \mathrm{mol} \mathrm{mL} \mathrm{min}^{-1}\right)$ & - & 0.042 & 0.449 & 0.393 & - & - & - & - & - & -
\end{tabular}

tryptic and alcalase CSPHs. The kinetic parameters of the reaction are summarised in Table 2. The apparent Michaelis constant $K_{m}^{\prime}\left(\mathrm{mg} \mathrm{mL}^{-1}\right)$ in the presence of peptic CSPHs was higher than those of tryptic and alcalase CSPHs at 0.5 $\mathrm{mg} \mathrm{mL}^{-1}$ and $1.5 \mathrm{mg} \mathrm{mL}^{-1}$ hydrolysate concentrations, and these peptic CSPH $K_{m}$ values were higher than these of $K_{m}$ of the inhibited reaction. Similarly, the $K_{m}^{\prime}$ in the presence of tryptic CSPH was higher than that of alcalase CSPH at 0.5 $\mathrm{mg} \mathrm{mL} \mathrm{mL}^{-1}$ and $1.0 \mathrm{mg} \mathrm{mL}^{-1}$ hydrolysate concentrations. The presence of peptic CSPH showed almost a concentrationdependent increase in $K_{m}$.

All CSPHs at all the study concentrations resulted

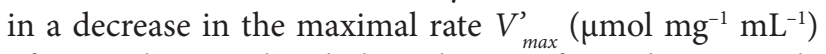
of a-amylase-catalysed degradation of starch to simple reducing sugars. $V_{\text {max }}^{\prime}$ in the presence of alcalase CSPH was lower than in the presence of both peptic and tryptic CSPHs. However, alcalase CSPH resulted in a lower $V_{\text {max }}^{\text {' }}$ than peptic CSPH. At all the hydrolysate concentrations, catalytic efficiency of $\alpha$-amylase was consistently reduced in a concentration-dependent manner. Alcalase CSPH, followed by tryptic CSPH, caused the highest reduction in the catalytic efficiency of $\alpha$-amylase. The enzyme-inhibitor dissociation constant $K_{i}\left(\mathrm{mg} \mathrm{mL}^{-1}\right)$ of $\alpha$-amylase inhibition by peptic CSPH $\left(K_{i}=0.042 \mathrm{mg} \mathrm{mL}^{-1}\right)$ was lower than those of tryptic $\left(0.449 \mathrm{mg} \mathrm{mL}^{-1}\right)$ and alcalase $(0.393 \mathrm{mg}$ $\left.\mathrm{mL}^{-1}\right)$ CSPHs. $K_{i}$ values for tryptic and alcalase CSPHs were approximately ten times as much as that of peptic CSPH, and the $K_{i}$ value for tryptic CSPH was higher than that of alcalase CSPH. The mode of $\alpha$-amylase inhibition exhibited by peptic, tryptic and alcalase CSPHs was non-competitive in all of the three cases (Fig. 3 to 5).

\section{Ferric-reducing antioxidant power}

Fig. 6 shows the ferric-reducing abilities of ascorbic acid and CSPHs which are expressed as the amount of $\mathrm{Fe}^{2+}$ released. The $\mathrm{Fe}^{3+}$-reducing power of ascorbic acid was higher ( $p$ $<0.05)$ than those of CSPHs. There was no significant difference $(p>0.05)$ between $\mathrm{Fe}^{3+}$-reducing abilities of CSPHs at all study concentrations, except that tryptic $\mathrm{CSPH}$, had significantly higher $\mathrm{Fe}^{3+}$-reducing ability than that of peptic and alcalase CSPHs at higher concentrations of 0.60 to $0.80 \mathrm{mg} \mathrm{mL}^{-1}$. All CSPHs, as well as ascorbic acid, exhibited concentration-dependent $\mathrm{Fe}^{3+}$-reducing power, except alcalase CSPH whose reducing power was not significantly different at all studied concentrations. $\mathrm{Fe}^{3+}$ reducing power of ascorbic acid was higher $(p<0.05)$ at all concentrations studied. $\mathrm{Fe}^{3+}$-reducing power of peptic hydrolysate was not significantly different at concentrations of 0.20 to $0.60 \mathrm{mg} \mathrm{mL}^{-1}$ but was significantly different at concentrations of 0.20 to $0.4 \mathrm{mg} \mathrm{mL}^{-1}$ and $0.80 \mathrm{mg}$ $\mathrm{mL}^{-1}$. $\mathrm{Fe}^{3+}$-reducing power of tryptic hydrolysate was significantly different $(p<0.05)$ at all of the concentrations studied except at 0.60 and $0.80 \mathrm{mg} \mathrm{mL}^{-1}$, where there was no significant difference $(p>0.05) . \mathrm{Fe}^{3+}$-reducing power

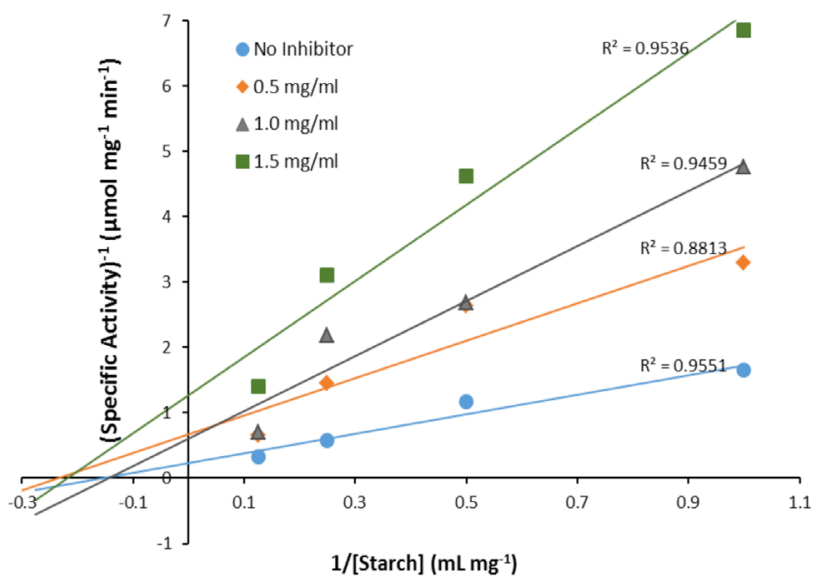

Fig. 4. Lineweaver-Burk plot of a-amylase inhibition by Citrullus lanatus seed protein hydrolysate derived from tryptic digestion.
Fig. 3. Lineweaver-Burk plot of $a$-amylase inhibition by Citrullus lanatus seed protein hydrolysate derived from peptic digestion.

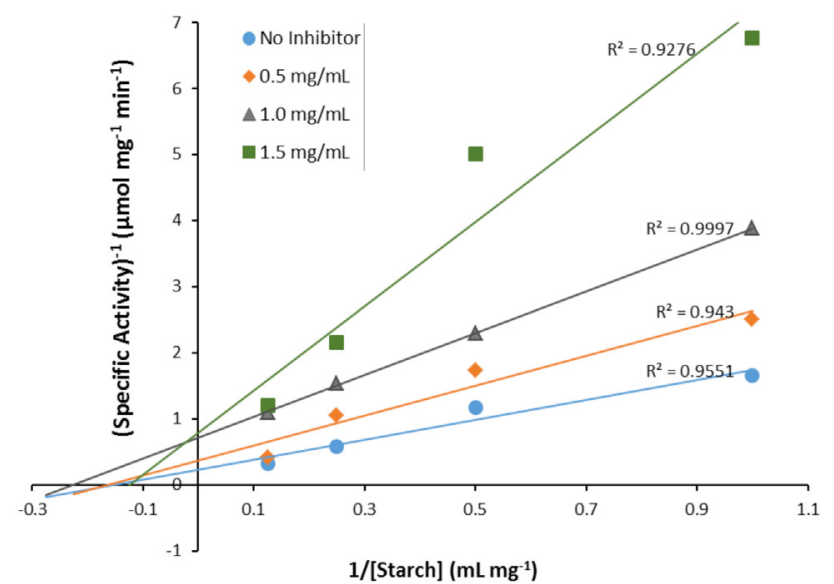




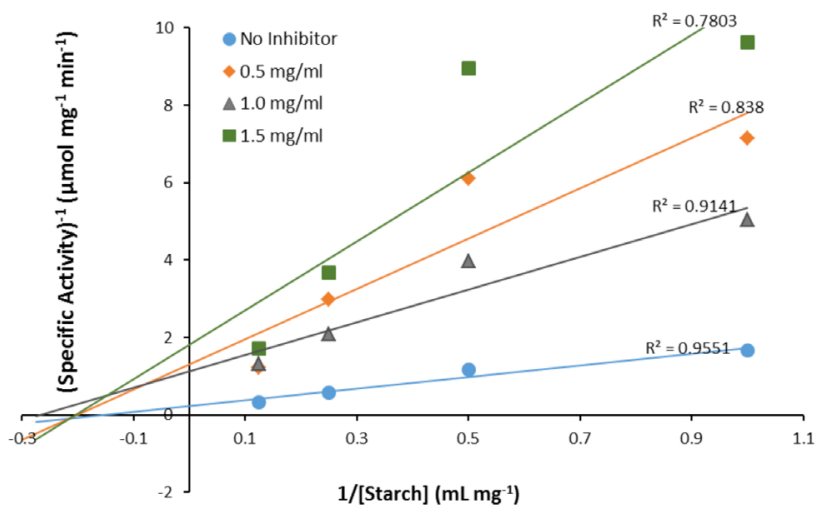

Fig. 5. Lineweaver-Burk plot of $a$-amylase inhibition by Citrullus lanatus seed protein hydrolysate derived from alcalase digestion.

of alcalase was not significantly different $(p>0.05)$ at all studied concentrations.

\section{Superoxide anion radical-scavenging capacity}

The percentage superoxide anion radical-scavenging capacity of the CSPHs is presented in Fig. 7. It is evident that the $\mathrm{O}_{2}^{-}$-scavenging activities of CSPHs and ascorbic acid were significantly different $(p<0.05)$ at all the study concentrations except tryptic CSPH whose percentage $\mathrm{O}_{2}^{-}$-scavenging capacity at $1.0 \mathrm{mg} \mathrm{mL}^{-1}$ and $2.0 \mathrm{mg} \mathrm{mL}^{-1}$ was not significantly different $(p>0.05)$ from that of alcalase CSPH. The percentage $\mathrm{O}_{2}^{-}$-scavenging activity of ascorbic acid was significantly higher than those of CSPHs. Of the hydrolysates, peptic CSPH exhibited the highest $\mathrm{O}_{2}{ }^{-}$-scavenging power. All CSPHs as well as ascorbic acid demonstrated concentration-dependent scavenging activity.

Fig. 8 shows the $50 \%$ inhibitory concentrations $\left(\mathrm{IC}_{50}\right)$ of CSPHs and ascorbic acid that inhibited pyrogallol

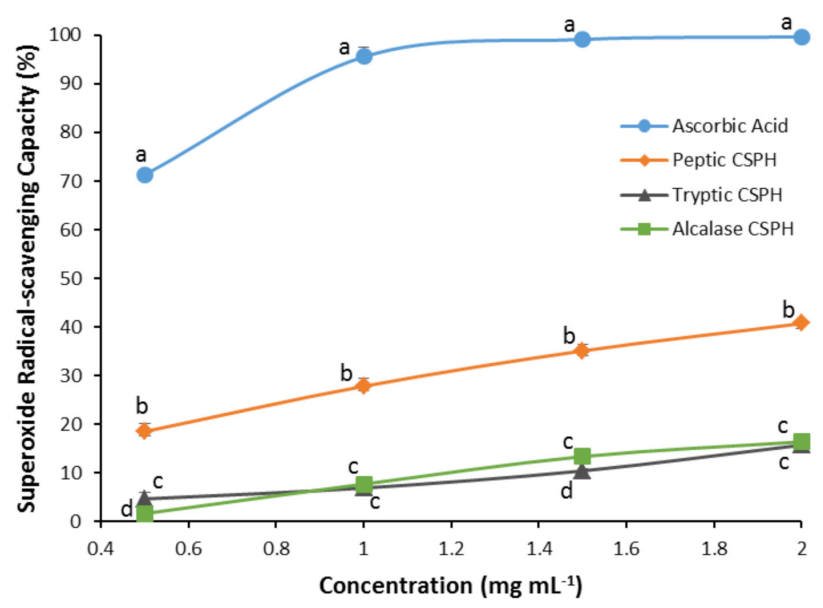

Fig. 7. Superoxide anion radical-scavenging capacity of Citrullus lanatus seed protein hydrolysates. Each dot represents the mean of triplicate determinations \pm SD. Dots belonging to different enzyme/sample and at the same concentration but with different letters are significantly different at $p<0.05$.

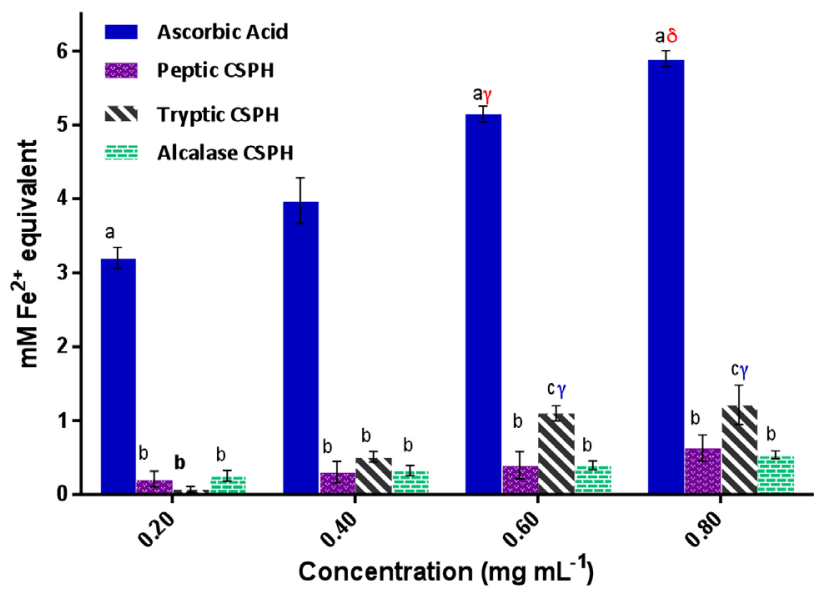

Fig. 6. Ferric-reducing antioxidant power of ascorbic acid and Citrullus lanatus seed protein hydrolysate. Each bar represents the mean of triplicate determinations \pm SD. Bars at the same concentration but with different Latin letters (abcd) are significantly different $(p<0.05)$. Bars of the same sample/enzyme at different concentrations with different Greek letters $(\alpha \beta \gamma \delta)$ are significantly different $(p<0.05)$.

autoxidation by $50 \%$. The $\mathrm{IC}_{50}\left(0.344 \mathrm{mg} \mathrm{mL}^{-1}\right)$ of ascorbic acid was lower $(p<0.05)$ than those of CSPHs. However, the $\mathrm{IC}_{50}$ value of peptic CSPH $\left(2.414 \mathrm{mg} \mathrm{mL}^{-1}\right)$ was significantly lower $(p<0.05)$ than those of tryptic $\left(2.824 \mathrm{mg} \mathrm{mL}^{-1}\right)$ and alcalase $\left(3.205 \mathrm{mg} \mathrm{mL}^{-1}\right) \mathrm{CSPHs}$, while the $\mathrm{IC}_{50}$ of tryptic CSPH was lower $(p<0.05)$ than that of alcalase CSPH.

\section{Discussion}

Percentage protein yield gives a measure of the extractable protein in a protein extraction procedure. The relatively low $18.91 \%$ protein yield obtained in this study might be

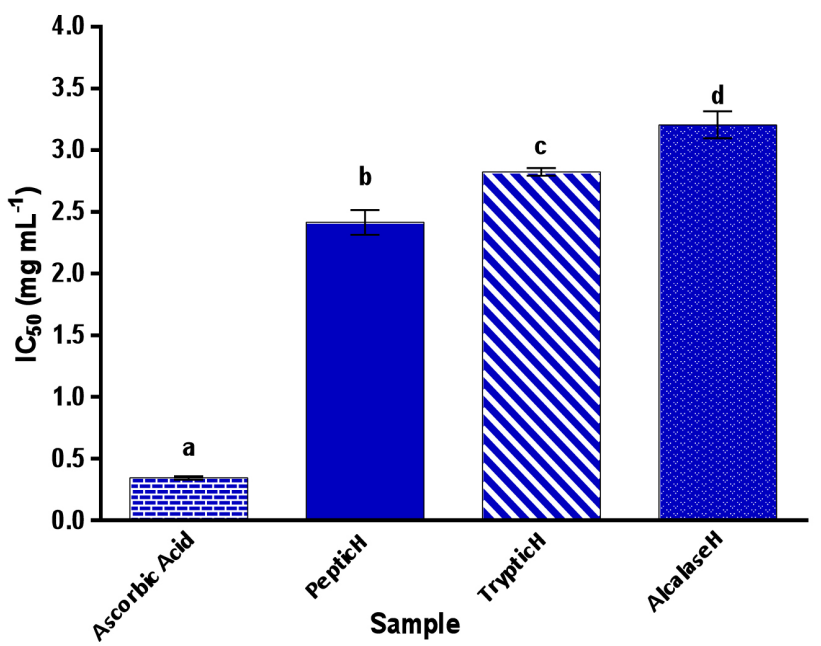

Fig. 8. Values of $50 \%$ inhibitory concentration $\left(\mathrm{IC}_{50}\right)$ of Citrullus lanatus seed protein hydrolysates in scavenging superoxide anion radical. Each bar represents the mean of triplicate determinations of $\mathrm{IC}_{50} \pm \mathrm{SD}$. Bars with different letters are significantly different at $p<0.05$. 
attributed to the extraction method employed. Boye et al. (2010) described that the level of protein yield is a function of the extraction method. The percentage protein yield obtained in this study was lower than $52 \%$ protein yield obtained for South African bambara groundnut landraces by Arise et al. (2015) using the acid-induced precipitation method of extraction. However, characterization studies on C. lanatus seed proteins have shown that globulins, which are salt-soluble proteins (Wani et al. 2010), represented the major fraction ranging between 57 and 67\% (Singh, Matta 2010). This might be the cause of the low protein yield obtained in that study, as being largely salt-soluble, some of the globulins might have been lost as insoluble polypeptides during extraction, even though it was expected that a larger portion would it be extracted with the introduction of hydrochloric acid for the induction of precipitation.

Degree of hydrolysis is often used to measure the number of peptide bonds cleaved during hydrolysis. It is often used as a proteolysis-monitoring parameter to ascertain the extent to which peptide bonds have been broken down to release short peptides (Jrad et al. 2014). The higher degree of hydrolysis by peptic and tryptic digestion, compared to that of alcalase, indicates the effectiveness of these two proteases in hydrolysing C. lanatus seed protein. These higher values reflect the possibility of presence of a large number of hydrophobic amino acid residues and acidic residues that pepsin is highly specific for; as well as positively charged residues for which trypsin is specific (Voet, Voet 2011; Naik 2012).

The degree of peptic hydrolysis (at enzyme-substrate $(\mathrm{E}: \mathrm{S})$ ratio of 1:100) obtained in this study was higher than the previously reported values of $\leq 5 \%$ (E:S of 2:100) and $\leq$ 8\% (E:S of 4:100) for hemp seed peptic protein hydrolysis (Malomo et al.2015). The degree of tryptic hydrolysis (26.26 $\pm 0.27 \%$ ) achieved in the present study is higher than $14.3 \pm$ $0.1 \%$ reported for Jelly fish protein hydrolysates by Zhuang et al. (2010); and $21.79 \pm 0.77 \%$ previously reported for whey protein tryptic hydrolysate where tryptic hydrolysis also had the highest DH (Kamau, Lu 2010). However, the $\mathrm{DH}(19.38 \pm 0.86 \%)$ obtained for pepsin is lower than the previously reported values for peptic hydrolysis of hemp seed protein (39.1\%; Girgih et al. 2011) and Australian canola protein (Alashi et al. 2014). The reported 46\% degree of tryptic hydrolysis of canola protein (Alashi et al. 2014) and $19 \%$ degree of alcalase hydrolysis of hemp seed protein (Girgih et al. 2011) were also higher than that obtained in this study. The low degree of alcalase hydrolysis may be attributed to the low E:S ratio because other studies with higher DH used a higher E:S ratio (Alashi et al.2014; Girgih et al. 2011; Li et al. 2011; Malomo et al. 2015; Udenigwe et al. 2009).

The $68.9 \%$ peptide yield of peptic digestion obtained in this study was slightly higher than the $65.7 \%$ previously reported for hemp seed peptic protein hydrolysis (Girgih et al. 2011). The higher percentage peptide yield of peptic digestion (68.9\%) could be attributed to the moderate specificity of pepsin where several residues are potential targets of its cleavage compared to the highly specific trypsin. However, the lower yield of alcalase hydrolysis may be due to the relatively low E:S ratio, even though the enzyme is generally non-specific. Although digestion using trypsin gave the highest degree of hydrolysis, the peptide yield obtained was significantly lower than that of peptic digestion. This may be attributed to the fact that trypsin cleaves at sites (containing basic amino acids) towards the C-terminal end, which could possibly have resulted in the generation of amino acids rather than peptides.

Although there is a large amount of information on $\alpha$-amylase inhibitors, studies and reports on the inhibition of $\alpha$-amylase activity by food-based hydrolysates are scarce despite the great potential of bioactive peptides in tackling various diseases. Based on the results of this study, alcalase and tryptic CSPHs showed remarkable inhibitory effects against $\alpha$-amylase activity. This is evident in the percentage inhibition attained by both alcalase (85.96\%) and tryptic (82.97\%) CSPHs. They exhibited concentration-dependent inhibitory activity with drastic response to increasing hydrolysate concentration. Peptic CSPH (70.19 \%) also demonstrated concentration-dependent inhibitory effect against $\alpha$-amylase, but the results showed that its response to increasing hydrolysate concentration was rather weak, compared to alcalase and tryptic CSPHs. However, alcalase CSPH had the best inhibition of $\alpha$-amylase activity, as it was also reflected in its low $\mathrm{IC}_{50}$ value $\left(0.1493 \mathrm{mg} \mathrm{mL}^{-1}\right)$.

The strong inhibition of $\alpha$-amylase by alcalase and tryptic CSPHs could be attributed to the type of amino acid residues often present in their cleavage products (i.e. cationic residues for trypsin) (Naik 2012). Alcalase, although generally non-specific, has been reported to have slight preference for sites having Trp, Tyr, Phe or Leu (Motyan et al. 2013). It could then be speculated that $\alpha$-amylase prefers to bind to peptides containing cationic and branched chain residues, such as Tyr, Phe, Trp, and Lys.

The $85.96 \%$ a-amylase-inhibitory activity attained (at $2.0 \mathrm{mg} \mathrm{mL}^{-1}$ ) by alcalase CSPH in this study is similar to the previously reported values for leaf extracts of Picralima nitida, even though the latter was at a much higher concentration of $10.0 \mathrm{mg} \mathrm{mL}^{-1}$ (Kazeem et al. 2013). The high $\mathrm{IC}_{50}$ of tryptic CSPH indicates that it was less potent compared to alcalase CSPH with a lower $\mathrm{IC}_{50}$ value.

Kinetic parameters obtained from the Lineweaver-Burk plot of $\alpha$-amylase inhibition by CSPHs were employed in determining the mechanism of the inhibition. The $K_{m}$ value of $\alpha$-amylase activity in the absence of inhibiting hydrolysates obtained in this study was $6.639 \mathrm{mg} \mathrm{mL}^{-1}$ $(0.664 \%$ starch), which is lower than $1 \%$ (starch) reported by Shobana et al. (2009). The pattern of the LineweaverBurk plots of $\alpha$-amylase-catalysed degradation of starch in the absence and presence of peptide inhibitors showed the mode of inhibition of $\alpha$-amylase by peptic, tryptic and 
alcalase CSPHs to be non-competitive inhibition type in all three cases. This means that the peptides contained in the hydrolysate could combine with $\alpha$-amylase molecule to produce an inactive (enzyme-inhibitor or enzymesubstrate-inhibitor) complex, irrespective of whether a substrate molecule is bound to the enzyme active site or not (Girgih et al. 2011). The mode of inhibition observed in this study is comparable to what was reported for pine bark extract (Shobana et al. 2009).

The effects of the hydrolysates on $V_{\max }$ of $\alpha$-amylasecatalysed starch hydrolysis showed a concentrationdependent reduction typical of the non-competitive mode of inhibition. The effect on catalytic efficiency CE of a-amylase also showed a concentration-dependent reduction. Peptic CSPH had significantly lower $K_{i}$ value $\left(0.042 \mathrm{mg} \mathrm{mL}^{-1}\right)$, even though it had the lowest $\alpha$-amylaseinhibitory effect. However, alcalase CSPH had a lower $K_{i}$ value $\left(0.393 \mathrm{mg} \mathrm{mL}^{-1}\right)$ than tryptic CSPH $\left(0.449 \mathrm{mg} \mathrm{mL}^{-1}\right)$. Alcalase CSPH also resulted to a lower $\alpha$-amylase $\mathrm{CE}$ than tryptic CSPH.

Potassium ferricyanide is widely used to assess the reducing capacity of hydrolysates for which higher absorbance indicates higher formation of ferrous ions as a result of reduction of ferric ions to ferrous ions denoting higher reducing power (Razali et al. 2015). This property is an indication of the ability of hydrolysate to serve as a reducing agent in redox reactions. Several studies have shown that there is a relationship between the reducing capacity of hydrolysate and their antioxidant activity.

The significantly lower reducing power of all hydrolysates at study concentrations in comparison with ascorbic acid indicates that CSPHs possess reducing power that is not comparable with that of ascorbic acid. However, CSPHs did exhibit reducing power at higher concentrations and generally in a concentration-dependent fashion. The results showed that tryptic CSPH possesses the highest $\mathrm{Fe}^{3+}$-reducing power at high concentrations. This may be due to the high degree of hydrolysis obtained with tryptic hydrolysis. Several studies have reported that there may be a direct correlation between degree of hydrolysis and ferric-reducing power, indicating that smaller peptides often exhibit higher reducing power (Vastag et al. 2011). The occurrence of no significant difference between peptic and alcalase CSPHs reducing abilities at all study concentrations indicates that they possess similar Fe3+reducing power even though peptic $\mathrm{CSPH}$ resulted in the formation of slightly higher amount of $\mathrm{Fe}^{2+}$.

A similar trend of results was also reported in a previous study by Nazeer and Kulandai (2012) where they found that the reducing power of muscle and skin protein hydrolysate from the giant kingfish increased with increasing concentrations and that these reducing activities were lower than that of the standard antioxidant. A similar observation was also reported by Zhu et al. (2006) on wheat germ protein hydrolysate.

Several studies have reported low $\mathrm{Fe}^{3+}$-reducing power for hydrolysates, which might be an indication that unfractionated hydrolysates usually possess low $\mathrm{Fe}^{3+}$-reducing power capacity (Zhu et al. 2006; Li et al. 2008; Vastag et al. 2011; Nazeer, Kulandai 2012; He et al. 2013). This could possibly be improved if hydrolysates are fractionated to peptides of varying molecular weights.

Superoxide anion radicals are the most common of in vivo free radicals generated in a variety of biological systems, either by autoxidation or via enzymatic activity (Lee et al. 2012). Although they cannot directly initiate lipid oxidation, superoxide radical anions are potential precursors of highly reactive species, such as hydroxyl radical ( $\mathrm{Li}$ et al. 2008). The significantly higher $\mathrm{O}_{2}^{-}$scavenging capacity of peptic CSPH with respect to other CSPHs indicates that peptic CSPH contained peptides that are able to inhibit the autoxidation of pyrogallol, thereby preventing the formation of $\mathrm{O}_{2}^{-}$. The scavenging power of peptic CSPH could also be attributed to the presence of acidic residues in the peptides generated through peptic cleavage. Pepsin is an endopeptidase with specificity for acidic and hydrophobic amino acid residues (Kageyama 2002; Naik 2012). The acidic residues could donate $\mathrm{H}$ atoms to the $\mathrm{O}_{2}^{-}$thus neutralising and converting them to more stable and harmless water molecules. It has also been reported that the presence of hydrophobic residues at terminal ends of peptides enhances the radical scavenging properties of peptides (Sarmadi, Ismail 2010). Each of the hydrolysates demonstrated radical-scavenging capacity in a concentration-dependent fashion.

The percentage $\mathrm{O}_{2}^{-}$-scavenging capacity of alcalase CSPH obtained in this study was lower than the reported values of $35.03,66.96$ and $82.5 \%$ for a certain peptide fraction of chickpea protein alcalase hydrolysate ( $\mathrm{Li}$ et al. 2008), of alfalfa leaf peptides (Xie et al. 2008) and Trichiurus haumela alcalase protein hydrolysate (Jin, Wu 2015) respectively. The $\mathrm{IC}_{50}$ of CSPHs reflected the level of effectiveness of each in scavenging $\mathrm{O}_{2}^{-}$. The lower $\mathrm{IC}_{50}$ value of peptic CSPH further corroborated its superiority over tryptic and alcalase CSPHs in scavenging $\mathrm{O}_{2}^{-}$.

The results obtained in this study showed that each of the CSPHs possessed antioxidant property exhibited through different mechanisms of reducing and radicalscavenging capacities. Hydrolysates obtained from the three proteases all demonstrated potent inhibition of $\alpha$-amylase activity. Alcalase CSPH exhibited the strongest inhibition of $a$-amylase activity followed by tryptic CSPH. However, peptic CSPH showed the highest radical-scavenging ability, while tryptic CSPH gave the highest reducing ability. The results suggest that tryptic CSPH may be a good candidate as a combined antioxidant and antihyperglycaemic agent. Thus, watermelon seed protein hydrolysates obtained through digestion by pepsin, trypsin and alcalase could offer bioactivities which might be harnessed towards the development of safer, affordable and effective nutraceuticals. This will also provide a means of converting the often unutilised seed to potential wealth. 


\section{References}

Adisakwattana S., Ruengsamran T., Kampa P., Sompong W. 2012. In vitro inhibitory effects of plant-based foods and their combinations on intestinal $\alpha$-glucosidase and pancreatic a-amylase. BMC Complem. Altern. Medic. 12: 1-8.

Alashi A.M., Blanchard C.L., Mailer R.J., Agboola S.O., Mawson A.J., He R., Malomo S.A., Girgih A.T., Aluko, R.E. 2014. Blood pressure lowering effects of Australian canola protein hydrolysates in spontaneously hypertensive rats. Food Res. Int. 55: 281-287.

Ali H., Houghton P.J., Soumyanath A. 2006. Alpha-amylase inhibitory activity of some Malaysian plants used to treat diabetes, with particular reference to Phyllanthus amarus. J. Ethnopharmacol. 107: 449-455.

Arise, R.O., Yekeen, A.A., Ekun, O.E and Olatomiwa, O.J. 2016. Angiotensin-I converting enzyme-inhibitory, antiradical and hydrogen peroxide-scavenging properties of Citrullus lanatus seed protein hydrolysates. Ceylon J. Sci. 45: 39-52.

Arise A.K., Amonsou E.O., Ijabadeniyi O.A. 2015. Influence of extraction methods on functional properties of protein concentrates prepared from South African bambara groundnut landraces. Int. J. Food Sci. Technol. 50: 1095-1101.

Asmat U., Abad K., Ismail K. 2015. Diabetes mellitus and oxidative stress - a concise review. Saudi Pharmac. J. 2015: 1-6.

Bernfield P. 1951. Enzymes of starch degradation and synthesis. Adv. Enzymol. 12: 379-380.

Boye J.I., Aksay S., Roufik S., Ribéreau S., Mondor M., Farnworth E.R., Rajamohamed S.H. 2010. Comparison of the functional properties of pea, chickpea and lentil protein concentrates processed using ultrafiltration and isoelectric precipitation techniques. Food Res. Int. 43: 537-546.

Erhirhie E.O., Ekene N.E. 2013. Medicinal values on Citrullus lanatus (watermelon): pharmacological review. Int. J. Res. Pharm. Biomed. Sci. 4: 1305-1312.

Gao R.M., Yuan Z.B., Zhao Z.Q., Gao X.R. 1998. Mechanism of pyrogallol autoxidation and determination of superoxide dismutase enzyme activity. Bioelectrochem. Bioenerg. 45: 4145.

Girgih A.T., He R., Hasan F.M., Udenigwe C.C., Gill T.A., Aluko R.E. 2015. Evaluation of the in vitro antioxidant properties of a cod (Gadus morhua) protein hydrolysate and peptide fractions. Food Chem. 173: 652-659.

Girgih A.T., Udenigwe C.C., Li H., Adebiyi A.P., Aluko R.E. 2011. Kinetics of enzyme inhibition and antihypertensive effects of hemp seed (Cannabis sativa L.) protein hydrolysates. J. Am. Oil Chem. Soc. 88: 1767-1774.

Gornall A.G., Bardawill C.J., David M.M. 1949. Determination of serum proteins by means of the biuret reaction. J. Biol. Chem. 177: 751-766.

Guyton A.C, Hall J.E. 2006. Textbook of Medical Physiology. $11^{\text {th }}$ Ed. Elsevier Saunders, Philadelphia.

He R., Girgih A.T., Malomo S.A., Ju X., Aluko R.E.2013.Antioxidant activities of enzymatic rapeseed protein hydrolysates and the membrane ultrafiltration fractions. J. Funct. Foods 5: 219-227.

Honga M.Y., Hartig N., Kaufman K., Hooshmand S., Figueroa A., Kern M. 2015. Watermelon consumption improves inflammation and antioxidant capacity in rats fed an atherogenic diet. Nutr. Res. 35: 251-258.

Jacob A.G., Etong, D.I., Tijjani A. 2015. Proximate, mineral and anti-nutritional compositions of melon (Citrullus lanatus) seeds. British J. Res. 2: 142-151.
Jin T., Wu Y.X. 2015. Antioxidant activities of protein hydrolysates from Little Hairtail (Trichiurus haumela) of East China Sea. Adv. J. Food Sci. Technol. 7: 354-360.

Jrad Z. 2014. Antioxidant activity of camel milk casein before and after in vitro simulated enzymatic digestion. Mljekarstvo 287-294.

Kageyama T.2002. Pepsinogens, progastricsins, and prochymosins: structure, function, evolution, and development. Cell. Mol. Life Sci. 59: 288-306.

Kamau S.M., Lu R. 2010. The effect of enzymes and hydrolysis conditions on degree of hydrolysis and DPPH radical scavenging activity of whey protein hydrolysates. Curr. Res. Diary Sci. 3: 25-35

Kayama Y., Raaz U., Jagger A. et al. 2015. Diabetic cardiovascular disease induced by oxidative stress. Int. J. Mol. Sci. 16: 2523425263.

Kazeem M.I., Ogunbiyi J.V., Ashafa A.O.T. 2013. In vitro studies on the inhibition of $\alpha$-amylase and $\alpha$-glucosidase by leaf extracts of Picralima nitida (Stapf). Tropical J. Pharm. Res. 12: 719-725.

Lee S.L., Kim K.H., Kim Y.S. et al. 2012. Biological activity from the gelatin hydrolysates of duck skin by-products. Process Biochem. 47: 1150-1154.

Li H., Prairie N., Udenigwe C.C., Adebiyi A.P., Tappia P.S., Aukema H.M., Jones P.J.H., Aluko R.E. 2011. Blood pressure lowering effect of a pea protein hydrolysate in hypertensive rats and humans. J. Agric. Food Chem. 59: 9854-9860.

Li Y., Jiang B., Zhang T., Mu W., Liu J. 2008. Antioxidant and free radical-scavenging activities of chickpea protein hydrolysate. Food Chem. 106: 444-50

Lipinski B. 2001 Pathophysiology of oxidative stress in diabetes mellitus. J. Diabetes Complic. 15: 203-210.

Malomo S., Onuh J., Girgih A., Aluko R. 2015. Structural and antihypertensive properties of enzymatic hemp seed protein hydrolysates. Nutrients 7: 7616-7632.

Matsui T., Yoshimoto C., Osajima K., Oki T., Osajima Y. 1996. In vitro survey of a-glucosidase inhibitory food components. Biosci. Biotechnol. Biochem. 60: 2019-2022.

Motyan J., Toth F., Tozser J. 2013. Research applications of proteolytic enzymes in molecular biology. Biomolecules 3: 923-942.

Mundi S., Aluko R.E. 2014. Inhibitory properties of kidney bean protein hydrolysate and its membrane fractions against renin, angiotensin converting enzyme, and free radicals. Austin J. Nutr. Food Sci. 2: 1-11.

Naik P. 2012. Protein metabolism. In: Essentials of Biochemistry. Jaypee Brothers Medical Publishers, pp. 226-257.

Nazeer R.A., Kulandai K.A. 2012. Evaluation of antioxidant activity of muscle and skin protein hydrolysates from giant kingfish, Caranx ignobilis. J. Food Sci. Technol. 47: 274-281.

Oboh G., Ademiluyi A.O., Faloye Y.M. 2011. Effect of combination on the antioxidant and inhibitory properties of tropical pepper varieties against $\alpha$-amylase and $\alpha$-glucosidase activities in vitro. J. Med. Food 14: 1152-1158.

Oyaizu M. 1986. Studies on products of browning reactions: antioxidative activities of 581 products of browning reaction prepared from glucosamine. Jap. J. Nutr. 44: 307-315.

Razali A. N., Amin A. M., Sarbon N. M. 2014. Antioxidant activity and functional properties of fractionated cobia skin gelatin hydrolysate at different molecular weight. Int. Food Res. J. 22: 651-660.

Sani U.M. 2014. Phytochemical screening and antidiabetic activity of extracts of Citrullus lanatus rind in alloxan-induced 
diabetic albino mice. Int. J. Chem. Pharm. Sci. 2: 1211-1215.

Sarmadi B. H., Ismail A. 2010. Antioxidative peptides from food proteins: A review. Peptides 31: 1949-1956.

Shobana S., Sreerama Y. N., Malleshi N. G. 2009. Composition and enzyme inhibitory properties of finger millet (Eleusine coracana L.) seed coat phenolics: Mode of inhibition of a-glucosidase and pancreatic amylase. Food Chem. 115: 12681273.

Singh N. P., Matta N. K. 2010. Levels of seed proteins in Citrullus and Praecitrullus accessions. Plant Syst. Evol. 290: 47-56.

Udenigwe C. C., Lin Y., Hou W., Aluko R. E. 2009. Kinetics of the inhibition of renin and angiotensin I-converting enzyme by flaxseed protein hydrolysate fractions. J. Funct. Foods 2009: 199-207.

Vastag Z, Popovic L., Popovic S., Krimer V., Pericin D. 2011. Production of enzymatic hydrolysates with antioxidant and angiotensin-I converting enzyme inhibitory activity from pumpkin oil cake protein isolate. Food Chem. 124: 1316-1321.

Voet D., Voet J.G. 2011. Biochemistry. $4^{\text {th }}$ ed. John Wiley \& Sons, Hoboken.

Wani A. A., Sogi D. S., Singh P., Wani I. A., Shivhare U. S. 2011. Characterisation and functional properties of watermelon (Citrullus lanatus) seed proteins. J. Sci. Food Agric. 91: 113-
121.

Xie Z., Huang J., Xu X., Jin Z. 2008. Antioxidant activity of peptides isolated from alfalfa leaf protein hydrolysate. Food Chem. 111: 370-376.

Yu Z., Liu B., Zhao W., Yin Y., Liu J., Chen F. 2012. Primary and secondary structure of novel ACE-inhibitory peptides from egg white protein. Food Chem. 133: 315-322

Zambrowicz A., Pokora M., Setner B., Dabrowska A., Szołtysik M., Babij K., Szewczuk Z., Trziszka T., Lubec G., Chrzanowska J. 2014. Multifunctional peptides derived from an egg yolk protein hydrolysate: isolation and characterization. Amino Acids 47: 369-380.

Zhang S. B., Wang Z., Xu S. Y. 2008. Antioxidant and antithrombotic activities of rapeseed peptides. J. Am. Oil Chem. Soc. 85: 521527.

Zhu K., Zhou H., Qian H. 2006. Antioxidant and free radicalscavenging activities of wheat germ protein hydrolysates (WGPH) prepared with alcalase. Process Biochem. 41: 12961302.

Zhuang Y.L., Sun L.P., Zhao X., Hou H., Li B.F. 2010. Investigation of gelatin polypeptides of jellyfish (Rhopilema esculentum) for their antioxidant activity in vitro. Food Technol. Biotechnol. 48: 222-228. 